Diabetologia 10, 667-670 (1974)

(C) by Springer-Verlag 1974

\title{
Decreased Intravenous Glucose Tolerance and Low Plasma Insulin Response in Spiny Mice* (Acomys cahirinus)
}

\author{
A. Gutzeit, A. Rabinovitch**, P.P.Studer, P.A. Trueheart, E. Cerasi*** and A. E. Renold \\ Department of Medicine, Institute of Clinical Biochemistry, University of Geneva, Genova, Switzerland
}

\begin{abstract}
Summary. A technique was developed to permit estimation of intravenous glucose tolerance and the concomitant immunoreactive insulin (IRI) response in the Geneva colony of the semi-desert rodent Acomys cahirinus. Following intravenous injection of glucose $1.5 \mathrm{~g} / \mathrm{kg}$, young Acomys (2-3 months, $25-35 \mathrm{~g}$ body weight) had a significantly lower glucose tolerance $(p<0.01)$ and a smaller $30 \mathrm{~min}$ integrated plasma IRI response $(p<0.001)$ than age and weight matched albino mice. With increasing age (8 and 21 months) and body weight (57 to $100 \mathrm{~g}$ ) of the Acomys, glucose tolerance and plasma IRI response decreased further, and in the 21 month old group there
\end{abstract}

were 2 overtly diabetic animals. There was a significant negative correlation between intravenous glucose tolerance and body weight in older Acomys. The results suggest that pancreatic B-cell responsiveness to glucose is impaired in Acomys of all ages, and that this is associated with poor glucose tolerance which may be aggravated by obesity.

Key words: Spiny mouse (Acomys cahirinus), intravenous glucose tolerance, insulin in plasma, obesity, endocrine pancreas, insulin secretion.

\section{Introduction}

The occurrence of a syndrome of carbohydrate intolerance and obesity, associated with considerable congenital hyperplasia of the islets of Langerhans, has previously been described in our colony of spiny mice, Acomys cahirinus $[5,8,10]$. Earlier experiments suggested that insulin release might be impaired in the Acomys [13], and more recently Cameron et al. $[2,3]$ demonstrated that plasma IRI responses to intraperitoneally administered glucose, theophylline, isoprenaline, or cyclic AMP were lower in Acomys than in Swiss albino mice. These experiments were limited by the absence of superficial veins in this semi-desert rodent, the inability to use intravenous injections hampering detailed analysis of glucose tolerance and associated insulin responses. The present experiments were made possible by the development of a technique permitting intravenous glucose administration and serial blood sampling in the Acomys.

\section{Materials and Methods}

Intravenous glucose tolerance was compared between normoglycemic Acomys and age- (2 to 3 months) and

* This work was supported by Grants nos. 3.384.70 and 3.1060 .73 of the Fonds National Suisse pour la Recherche Scientifique, Bern, Switzerland, and by the Fondation Education et Recherche, Basel, Switzerland.

** Centennial Fellow of the Medical Research Council of Canada.

*** On leave from the Department of Endocrinology and Metabolism, Karolinska Hospital, Stockholm, Sweden; Visiting Professor at the University of Geneva; Recipient of Pfizer Travel Award through the European Association for the Study of Diabetes. weight- (25 to $35 \mathrm{~g})$ matched Swiss albino mice. In addition, older Acomys at the age of 8 months ( 57 to $79 \mathrm{~g}$ ) and of 21 months ( 57 to $100 \mathrm{~g}$ ) were tested. In the latter group there were two diabetic animals. All animals were bred in our own laboratory and fed ad libitum until the time of experimentation between $9-10 \mathrm{a} . \mathrm{m}$. The animals were anesthetized with sodium pentobarbital (Nembutal, Abbott Laboratories, North Chicago, Illinois, U.S.A.) $50 \mathrm{mg} / \mathrm{kg}$ injected intraperitoneally and $25 \mathrm{mg} / \mathrm{kg}$ subcutaneously. A femoral vein was exposed and, using a butterfly infusion set with a $\mathrm{G} 25$ short needle (Abbott), glucose $1.5 \mathrm{~g} / \mathrm{kg}$ was injected as a $20 \%$ solution during 50 to 60 sec. Injection was carried out by visualization through a binocular dissecting microscope. After the test the wound was closed with metal clips. The animals tolerated the procedure well.

Sequential blood sampling was performed by puncture of the retro-orbital venous plexus [12] using heparinized hematocrit capillary tubes before and 2,5 , 15 and 30 min after the injection of glucose. A total of 500 to $600 \mu \mathrm{l}$ of blood was withdrawn from each animal in one test. The individual blood samples were immediately transferred to heparinized microcentrifuge tubes, kept at $4^{\circ} \mathrm{C}$ and, within $30 \mathrm{~min}$, centrifuged for 3 min in a microcentrifuge (Greiner Electronic, Langenthal, Switzerland).

Plasma glucose was determined on $5 \mu \mathrm{l}$ samples in duplicate using a glucose-oxidase method (GOD-POD kits, kindly supplied by Boehringer Mannheim, Germany).

Immunoreactive insulin (IRI) was measured on $10 \mu \mathrm{l}$ samples in duplicate, using the charcoal separation method of Herbert et al. [6] adapted to small volumes. Assay incubations were carried out in small 
(350 $\mu 1$ capacity) plastic microcentrifuge tubes (Beckman Corp., Palo Alto, California, U.S.A.) in a total volume of $110 \mu l: 10 \mu l$ plasma or insulin standard (kindly donated by Dr. J. Schlichtkrull, Novo Industri, Copenhagen, Denmark), $50 \mu l$ anti-pork insulin guinea pig serum (kindly donated by Dr. P. Wright, Indianapolis, Indiana, U.S.A.), and $50 \mu \mathrm{l}$ (about $5 \mathrm{pg}$ ) ${ }^{\text {225 I- }}$ insulin, iodinated by the method of Hunter and Greenwood [7] and purified on G-25 fine Sephadex (Pharmacia, Uppsala, Sweden). Human insulin was used as standard for assay of Acomys plasma samples, since Acomys plasma dilutions were parallel to human (or pork) insulin standards (but not to rat or mouse standards), assayed with anti-pork insulin serum. Mouse insulin was used as standard for assay of albino mouse plasma samples. Insulin standards, antiserum and ${ }^{125} \mathrm{I}$-insulin were diluted in $0.2 \mathrm{M}$ glycine buffer $\mathrm{pH} 8.8$, containing $0.25 \mathrm{~g} / 100 \mathrm{ml}$ human serum alloumin (Swiss Red Cross, Bern, Switzerland). After incubation for 2 to 3 days at $4^{\circ} \mathrm{C}, 20 \mu \mathrm{l}$ of beef serum (obtained from the local abattoir) was added as a protein carrier to tubes with insulin standards, and $20 \mu \mathrm{l}$ of beef serum diluted with an equal volume of glyeine buffer was added to tubes with plasma samples. Antibody-bound insulin was then separated from the unbound fraction by addition of $50 \mu \mathrm{l}$ of a suspension of $3.0 \mathrm{~g}$ charcoal (C 5260 Sigma Chem., St. Louis, Missouri, U.S.A.) and $0.25 \mathrm{~g}$ dextran-70 (Pharmacia, Stockholm, Sweden) in $100 \mathrm{ml}$ glycine buffer, $\mathrm{pH}$ 8.8, without human serum albumin. After a 3 min centrifugation in the microcentrifuge the supernatants were aspirated and the charcoal pellets counted for 5 min in a Gamma Scintillation Spectrometer (Packard, Downers Grove, Illinois, U.S.A.). The minimal sensitivity of this assay was $0.5 \mathrm{ng} / \mathrm{ml}$. Between 0.5 and $2.0 \mathrm{ng} / \mathrm{ml}$, the interassay coefficient of variation was $13 \%$ and the intraassay coefficient was $8 \%$.

\section{Results}

Fig. 1 compares plasma glucose (mean \pm SEM) after intravenous injection of $1.5 \mathrm{~g} / \mathrm{kg}$ of glucose into the femoral vein of albino mice (shaded area) and Acomys of different ages. Preinfusion $(0 \mathrm{~min})$ plasma glucose values were similar in the different groups. 2 min after the glucose infusion, plasma glucose levels were significantly higher for the 8 and 21 month old Acomys than for the 2 to 3 month old Acomys or albino mice $(p<0.001)$, possibly reflecting the decrease in extracellular space relative to body weight in the older, more obese Acomys. The subsequent decreases of plasma glucose are calculated as per cent of glucose cleared per $\min \left(\mathrm{K}_{\mathrm{g}}\right)$ as shown in Table 1. Glucose disposal $\left(\mathrm{K}_{\mathrm{g}}\right)$ was significantly lower $(p<0.01)$ in 2 to 3 month old Acomys (1.98 $50.22 \%$ per $\min$ ) than in age- and weight- matched albino mice ( $3.08 \pm 0.25 \%$ per min). Glucose disposal was decreased further in the older Acomys, although the difference between Acomys of different ages was not significant. There was, however, a significant negative correlation between glucose disposal and body weight $(r=-0.51, p<0.01)$ in the older Acomys (8 and 21 months) (Fig. 3, upper panel).

Table 1 indicates that preinfusion plasma glucose values were similar in all four normoglycemic animal groups, but were significantly elevated $(p<0.001)$ in the two 21 month old diabetic Acomys. Furthermore, Table 1 indicates that preinfusion plasma IRI levels were similar in the young $A$ comys $(1.4 \pm 0.2 \mu \mathrm{g} / \mathrm{ml})$ and the age and weight matched albino mice $(1.7 \pm 0.4 \mathrm{ng} /$ ml). 8 months old Acomys had significantly higher preinfusion plasma IRI levels $(3.7 \pm 0.4 \mathrm{ng} / \mathrm{ml}, p<$ 0.01 ), than did Acomys aged 2 to 3 months, whereas the elevation was less in the 21 month old Acomys group $(2.0+0.4 \mathrm{ng} / \mathrm{ml}$, NS). In the two diabetic animals there was no elevation of preinfusion plasma IRI (1.67 and $0.75 \mathrm{ng} / \mathrm{ml}$.
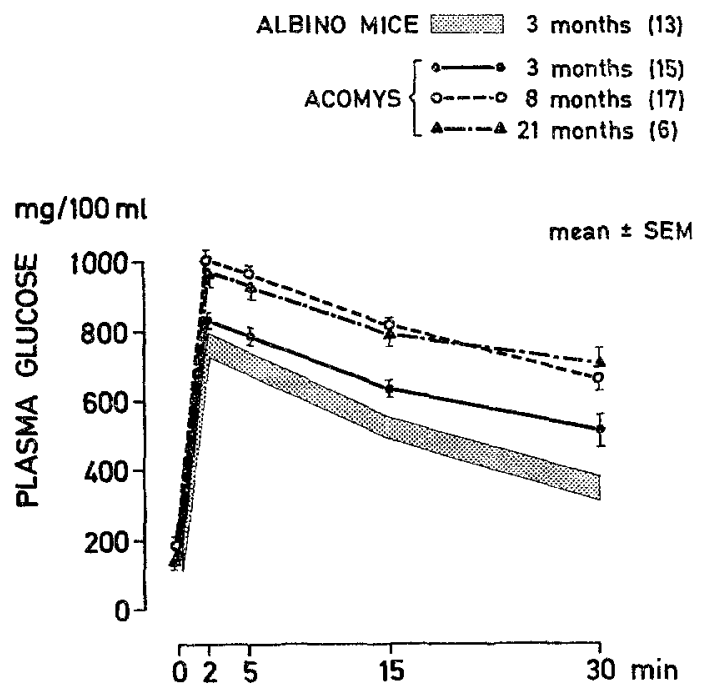

Fig. 1. Plasma glucose before, and at 2, 5, 15 and $30 \mathrm{~min}$ after intravenous injection of glucose $1.5 \mathrm{~g} / \mathrm{kg}$ in albino mice, age 2-3 months (shaded area, representing mean \pm SEM, $\mathrm{n}=13$ ); acomys, age 2-3 months (- $\mathrm{n}=$ 15); acomys, age 8 months (o-m-no $\mathrm{n}=17$ ); and acomys age 21 months $(\mathbf{A - \Lambda} \mathbf{n}=6$ ). Mean \pm SEM are given

Fig. 2 compares the increase in plasma IRI from preinfusion levels after infusion of glucose in the different animals. The differences in the plasma IRI responses between the group of albino mice and any of the group of Acomys were most marked at $2 \min (p<$ $0.001)$ and at $5 \mathrm{~min}(p<0.01)$ after glucose injection. At 15 and $30 \mathrm{~min}$ the differences were smaller $(p<0.05)$ or not statistically significant. Plasma IRI responses are also calculated as insulinogenic indices, obtained by dividing the incremental plasma IRI values integrated over $30 \mathrm{~min}$ following the injection of glucose by the corresponding incremental integrated plasma glucose values. Table 1 shows that the insulinogenic index for 2 to 3 month old Acomys (47.6 \pm 11.6$)$ was significantly lower $(p<0.001)$ than that for albino mice $(137.2 \pm$ 17.6). The insulinogenic indices were further decreased 
in the 8 months $(11.4 \pm 5.8)$ and 21 months $(26.0 \pm$ 14.5) Acomys, and the lowest indices were observed in the two diabetic Acomys (6.5 and 8.3).

\section{Discussion}

The intravenous injection procedure and a microassay for the measurement of IRI as described in this report enabled us to study the kinetics of insulin or glucosuric, the intravenous glucose tolerance in these animals was clearly reduced when compared to age and weight matched albino mice. Obviously, since no criteria are available, we cannot state whether or not these animals should be considered as chemical diabetics, but the finding of two diabetic animals among the 21 month old Acomys group would favour this possibility. The insulin response to the sudden elevation of blood glucose appeared to be as rapid in the young Acomys as in the albino mice, but the

Table 1. Glucose disposal ( $K_{g}$-rate), preanfusion plasma glucose and IRI levels, and insulinogenic indices (A IRI/A Glucose) during intravenous glucose tolerance test in albino mice and Acomys

\begin{tabular}{|c|c|c|c|c|c|c|c|c|c|c|}
\hline Rodent & $\begin{array}{l}\text { Age } \\
\text { months }\end{array}$ & (n) & $\begin{array}{l}\mathrm{K}_{\mathrm{g}} \text { rate } \\
\% \text { per } \\
\text { min }\end{array}$ & $\begin{array}{l}\mathrm{p} v s . \\
\text { mice }\end{array}$ & $\begin{array}{l}\text { Preinfusion } \\
\text { glucose } \\
\mathrm{mg} / 100 \mathrm{ml}\end{array}$ & $\begin{array}{l}\mathrm{p} v s . \\
\text { mice }\end{array}$ & $\begin{array}{l}\text { Preinfusion } \\
\text { IRI } \\
\mathrm{ng} / \mathrm{ml}\end{array}$ & $\begin{array}{l}\mathrm{p} v s . \\
\text { mice }\end{array}$ & $\frac{\Delta \text { IRI }}{\Delta \text { Glucose }}$ & $\begin{array}{l}\mathrm{p} v s . \\
\text { mice }\end{array}$ \\
\hline $\begin{array}{r}\text { Albino } \\
\text { mice }\end{array}$ & $2-3$ & (13) & $\begin{array}{r}3.08 \\
+0.25\end{array}$ & - & $\begin{array}{r}176.0 \\
+\quad 13.3\end{array}$ & - & $\begin{array}{r}1.7 \\
\pm 0.4\end{array}$ & - & $\begin{array}{r}137.2 \\
\pm \quad 17.6\end{array}$ & - \\
\hline Acomys & $2-3$ & $(15)$ & $\begin{array}{r}1.98 \\
\pm 0.22\end{array}$ & $<0.01$ & $\begin{array}{r}153.7 \\
\pm \quad 10.0\end{array}$ & NS & $\begin{array}{r}1.4 \\
\pm 0.2\end{array}$ & NS & $\begin{array}{r}47.6 \\
\pm \quad 11.6\end{array}$ & $<0.001$ \\
\hline Acomys & 8 & (17) & $\begin{array}{r}1.62 \\
\pm 0.19\end{array}$ & $<0.001$ & $\begin{array}{r}182.6 \\
\pm \quad 13.9\end{array}$ & NS & $\begin{array}{r}3.7 \\
\pm 0.4\end{array}$ & $<0.005$ & $\begin{array}{r}11.4 \\
\pm \quad 5.8\end{array}$ & $<0.001$ \\
\hline Acomys & 21 & (6) & $\begin{array}{r}1.49 \\
\pm 0.32\end{array}$ & $<0.005$ & $\begin{array}{r}135.2 \\
+\quad 9.8\end{array}$ & NS & $\begin{array}{r}2.0 \\
\pm 0.4\end{array}$ & NS & $\begin{array}{r}26.0 \\
+\quad 14.5\end{array}$ & $<0.001$ \\
\hline $\begin{array}{l}\text { Acomys } \\
\text { diabetic }\end{array}$ & 21 & $\begin{array}{l}\text { (a) } \\
\text { (b) }\end{array}$ & $\begin{array}{l}0.6 \\
1.22\end{array}$ & & $\begin{array}{l}533 \\
534\end{array}$ & & $\begin{array}{l}1.67 \\
0.75\end{array}$ & & $\begin{array}{l}6.5 \\
8.3\end{array}$ & \\
\hline
\end{tabular}

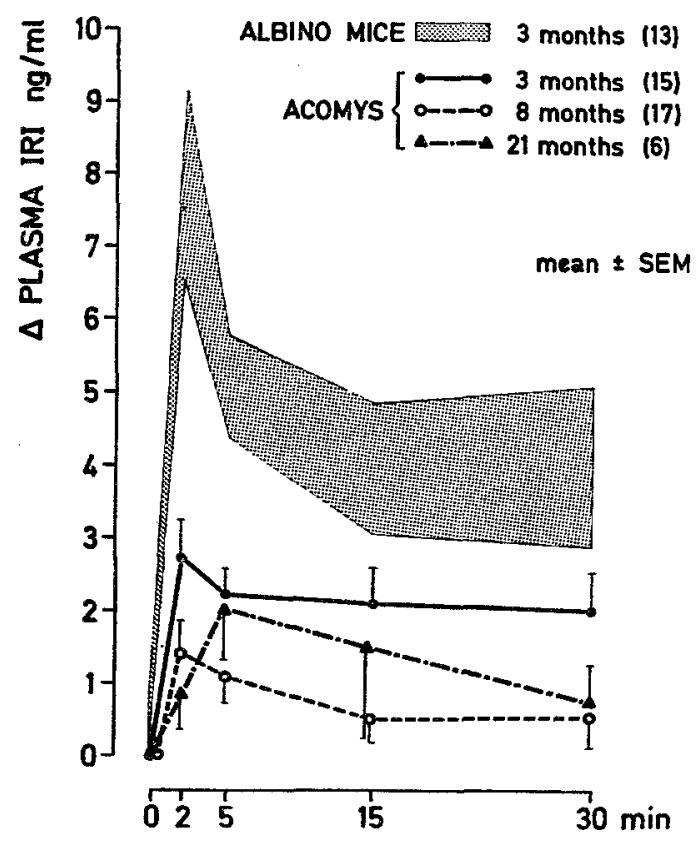

Fig. 2. Increase $(\Delta)$ in plasma IRI above preinfusion levels 2, 5, 15 and 30 min after intravenous injection of glucose. Symbols as for Fig. 1

release during glucose tolerance tests in Acomys cahirinus. This rodent has previously been shown to be defective in insulin secretion [2] and to have an increased incidence of spontaneous diabetes [5]. Although none of the young Acomys tested were hyperglycemic
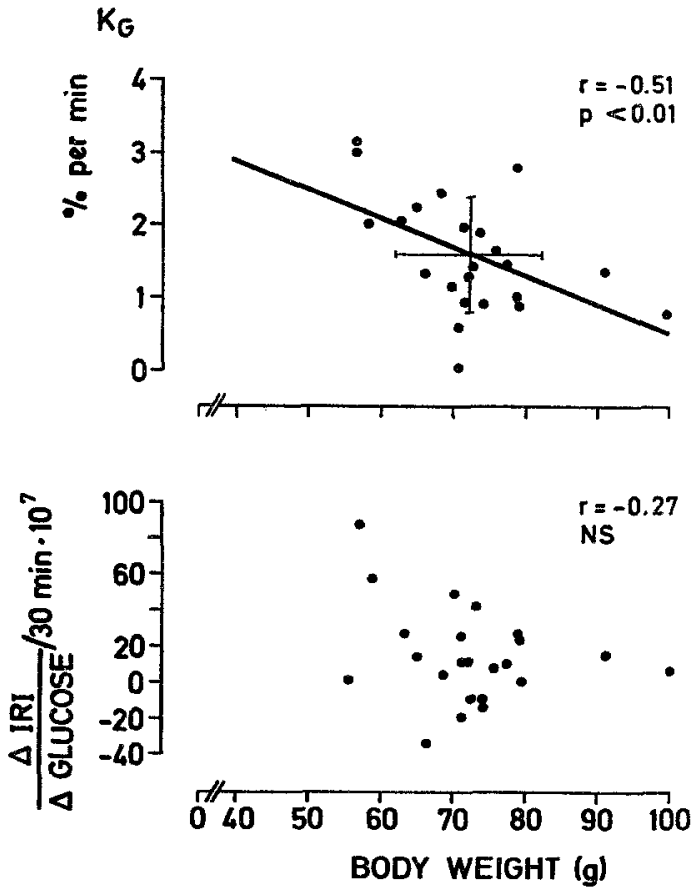

Fig. 3. Correlation between glucose disposal $\left(K_{g}\right.$, panel above) or insulinogenic index ( $\Delta$ IRI/ $\Delta$ glucose, panel below) and body weight of individual $A$ comys age 8 and 21 months $(n=23)$ after intravenous injection of glucose $1.5 \mathrm{~g} / \mathrm{kg}$. Mean $\pm 1 \mathrm{~S} . \mathrm{D}$. are shown for $\mathrm{K}_{\mathrm{g}}$ rate and body weight. Insulinogenic index is calculated as incremental plasma IRI values integrated over $30 \mathrm{~min}$ following injection of glucose, divided by the corresponding area under the plasma glucose curve 
magnitude of the response was markedly diminished. Although in the Acomys the lessening of the insulin response was more pronounced soon after glucose administration, both its initial and late phases were affected. This is also shown by the markedly lower insulinogenic index values for the integrated (30 min) insulin response, which mainly reflects the late secretion phase. In these respects the Acomys is reminiscent of human subjects with chemical diabetes or low insulin response in whom glucose tolerance is slightly to moderately reduced, while insulin response to glucose is markedly diminished (with emphasis on the initial response) [4]. It must be borne in mind, however, that the glucose infusions presented in this report were performed while the animals were under Nembutal anesthesia, a condition which has been shown to affect both glucose tolerance and insulin secretion [1]. Therefore, whether the glucose and insulin data given here do represent the actual in vivo situation in the animals must remain an open question.

Acomys develop moderate obesity with increasing age [5], and obesity is known to be accompanied by enhanced insulin secretion in many animal species [3] and in man [9]. In the Acomys of older age groups (8 and 21 months) the level of circulating insulin before glucose administration was indeed higher than in the younger and leaner animals. However, no enhancement of the insulin response to glucose injection could be observed in these obese Acomys. There was no correlation between the insulinogenic index and body weight in the older animals (Fig. 3, lower panel) in spite of the wide range in weights ( 57 to $100 \mathrm{~g}$ ). Nevertheless, the lower insulin response to glucose demonstrated in the older Acomys suggests that B-cell responsiveness decreases with age. This possibly masks the expected increase in insulin response with obesity. Furthermore, the B-cell defect presumably inherent in the Acomys may limit the free expression of obesity as a stimulating factor for insulin secretion. A similar situation appears to exist in mice of the obese hyperglycemic strain DBM in which the more hyperglycemic animals demonstrate higher basal (fasting) plasma insulin levels but smaller insulin responses to glucose [3].

Since obesity is associated with insulin resistance [11] one would expect deterioration of glucose tolerance in the Acomys whose insulin secretion was not enhanced by obesity. Indeed, as shown in Fig. 3, a significant negative correlation was found between glucose tolerance $\left(\mathrm{K}_{\mathrm{g}}\right)$ and body weight in the higher age group of Acomys, where obesity is more apparent. Since glucose tolerance of 21 month old animals (the diabetic animals excluded) was not significantly different from that of 8 months old Acomys, it is probable that this lesser glucose tolerance may be more closely related to obesity than to ageing. The eventual development of marked or severe glucose intolerance in Acomys may depend on the balance between the gradual reduction in insulin response with age, the degree of enhancement of the islet function induced by obesity, and the severity of resistance to insulin that may accompany this state.

Acknowledgements. The authors express their gratitude to Mrs. Savina Kalfopoulos for her expert technical assistance, and to Mr. Raymond Cuche for outstanding animal care.

\section{References}

1. Aynsley-Green, A., Biebuyck, J.F., Alberti, K.G.M. M.: Anaesthesia and insulin secretion: the effects of diethyl ether, halothane, pentobarbitone sodium and ketamine hydrochloride on intravenous glucose tolerance and insulin secretion in the rat. Diabetologia $\mathbf{9}$, $274-281$ (1973)

2. Cameron, D.P., Stauffacher, W., Orci, L., Amherdt, M., Renold, A.E.: Defective immunoreactive insulin secretion in the Acomys cahirinus. Diabetes 21, 1060$1071(1972)$

3. Cameron, D.P., Stauffacher, W., Amherdt, M., Orci, L., Renold, A. E. : Kinetics of immunoreactive insulin release in obese hyperglycemic laboratory rodents. Endocrinology 92, 257-264 (1973)

4. Cerasi, E., Luft, R.: Plasma insulin responses to glucose infusion in healthy subjects and in diabetes mellitus. Acta endocr. (Kbh.) 55, 278-304 (1967)

5. Gonet, A. E., Stauffacher, W., Pictet, R., Mougin, J., Renold, A.E.: Obesity and diabetes mellitus with striking congenital hyperplasia of the islets of Langerhans in spiny mice (Acomys cahirinus). Diabetologia $1,162-171(1965)$

6. Herbert, V., Lau, K.-S., Gottlieb, C.W., Bleicher, S.J.: Coated charcoal immunoassay of insulin. J. clin. Endoer. 25, 1375-1384 (1965)

7. Hunter, W.M., Greenwood, F.C.: Preparation of iodine-131 labelled human growth hormone of high specific activity. Nature (Lond.) 194, 495-496 (1962)

8. Junod, A., Letarte, J., Lambert, A. E., Stauffacher, W.: Studies in spiny mice (Acomys cahirinus): metabolic state and pancreatic insulin release in vitro. Horm. Metab. Res. 1, 45-52 (1969)

9. Perley, M.J., Kipnis, D.M.: Plasma insulin responses to glucose and tolbutamide of normal-weight and obese diabetic and non-diabetic subjects. Diabetes 15, $867-874(1966)$

10. Pictet, R., Orci, L., Gonet, A.E., Rouiller, C., Renold, A.E.: Cltrastructural studies of the hyperplastic islets of Langerhans of spiny mice (Acomys cahirinus) before and during the development of hyperglycemia. Diabetologia $3,188-211$ (1967)

11. Rabinowitz, D., Zierler, K.L.: Forearm metabolism in obesity and its response to intra-arterial insulin. J. clin. Invest. 41, 2173-2181 (1962)

12. Riley, V.: Adaptation of orbital bleeding technic to rapid serial blood studies. Proc. Soc. Exp. Biol. (N.Y.) 104, $751-754(1961)$

13. Stauffacher, W., Orci, L., Amherdt, M., Burr, I.M., Balant, L., Froesch, E.R., Renold, A. E.: Metabolic state, pancreatic insulin content and $\beta$-cell morphology of normoglycemic spiny mice (Acomys cahirinus): indications for an impairment of insulin secretion. Diabetologia 6, 330-342 (1970)

\section{Dr. A. Gutzeit}

Department of Medicine Institute of Clinical Biochemistry University of Geneva CH-1211 Geneva 4 Switzerland 